\title{
Beyond variegation: the territorialisation of states, communities and developers in large-scale developments in Johannesburg, Shanghai and London
}

\section{FOR SPECIAL ISSUE: J. ROBINSON (ED): Comparative methods for global urban studies}

Jennifer Robinson ${ }^{1}$ (University College London), Fulong Wu (University College London), Phil Harrison (University of the Witwatersrand), Zheng Wang (University of Sheffield), Alison Todes (University of the Witwatersrand), Romain Dittgen (University of the Witwatersrand), Katia Attuyer (Xi' an Jiaotong- Liverpool University)

\begin{abstract}
Large-scale urban development projects are a significant format of urban expansion and renewal across the globe. As generators of governance innovation and indicators of the future city in each urban context, large-scale development projects have been interpreted within frameworks of "variegations" of wider circulating processes, such as neoliberalisation or financialisation. However, such projects often entail significant state support and investment, are strongly linked to a wide variety of transnational investors and developers and are frequently highly contested in their local environments. Thus, each project comes to fruition in a distinctive regulatory context, often as an exception to the norm, and each emerges through complex interactions over a long period of time amongst an array of actors. We therefore seek to broaden the discussion from an analytical focus on variegated globalised processes to consider three large-scale urban development projects (in Shanghai, Johannesburg and London) as distinctive (transcalar) territorialisations. Using an innovative comparative approach we outline the grounds for a systematic analytical conversation across mega-urban development projects in very different contexts. Initially, comparability rests on the shared features of large-scale developments - that they are multi-jurisdictional, involve long time scales, and bring significant financing challenges. Comparing three development projects we
\end{abstract}

\footnotetext{
${ }^{1}$ Corresponding author: Jennifer Robinson, Department of Geography, UCL, 26 Bedford Way, WC1H 0AP, UK. Email: Jennifer.Robinson@ucl.ac.uk.
} 
are able to interrogate, rather than take for granted, how wider processes, circulating practices, transcalar actors, and territorial regulatory formations composed specific urban outcomes in each case. Thinking across these diverse cases provides grounds for rebuilding understandings of urban development politics.

\section{Keywords}

Large-scale urban development; urban politics; financing; state-community relations; developers; comparative urbanism

\section{Introduction}

The territorial formations of the urban under planetary urbanization (extended, fragmented, sprawling, operational) imply the need to move beyond a jurisdictional municipal approach to understanding urban development politics - a range of territories, territorialisations and spatial dynamics need to be taken into account (Brenner and Schmid, 2015; Lauermann, 2018; Keil, 2017; Murray, 2017; Kanai and Schindler, 2019; Choplin and Hertzog, 2020). Based on the example of large-scale urban developments in three different contexts (Shanghai, London and Johannesburg), we propose an approach to urban politics which can potentially speak to a wide range of emergent urban territories in the midst of interconnected but also often dispersed and fragmented urban outcomes. We suggest it is important to move away from the analytical focus on competing municipalities interacting with footloose capital, as framed through the US experience (Lauermann, 2018; Robinson, 2021). We also want to reach beyond the spatial analytic of "variegation" which emphasises the wider processes involved to the detriment of direct analytical focus on the emergent territorialisations; in this perspective, contexts have a relatively limited role, as hybridizing or adding variety to wider processes. We propose an approach which is relevant to the diverse territorialisations of urban politics e.g. large scale development 
projects, satellite cities, peripheral urbanization, extensive infrastructural developments. In these settings a diverse cast of actors is assembled, with differently configured interests and concerns, varying from context to context (even within the same city, region or country). Rather than contributing to elaborating pre-existing concepts, such as neoliberalisation, we propose a methodology which is open to identifying a wider variety of social processes and political dynamics. We thus seek to build insights, comparatively, across a diversity of emergent political formations, to open up new grounds for conceptualising urban politics from a wide range of urban experiences.

We begin from an understanding of the urban as "specific" - each urban outcome is distinctive (Schmid, 2015). Thus, we take seriously Henri Lefebvre's caution that "the city's transformations are not the passive outcomes of changes in the social whole" (1996, p. 100); the urban is more than the sum of already identified wider processes. We are inspired to move beyond a view of the urban as variegated outcomes of social processes, or conjunctures of intersecting processes and wider social formations. Following Lefebvre, we can consider the urban as a three-dimensional and lived spatiality, mediating global and private spheres (Schmid, 2005; 2008), and as an emergent totality based on diverse processes of becoming, in which "relations and determinations" are embedded in/emergent from the urban itself, and from social and spatial praxis (Lefebvre, 2003; 2009; Goonewardena, 2018). We appreciate specific urban contexts are enmeshed in "pan-urban" processes, with implications for the complex spatialities of contemporary urbanisation:

"the capitalist urban fabric is no longer organized as an encompassing, worldwide grid of national city- systems, neatly subdivided into internal central place hierarchies, but is instead unevenly differentiated among variegated places, regions, territories, and landscapes whose mottled connective tissue more closely resembles that of an intricately stitched latticework than a simple pyramid, hierarchy, or grid" (Brenner, 2019, p. 12). 
In the wake of a long debate in urban studies and geography (Brenner, 2005; Allen and Cochrane, 2007) the metaphor of "scale" does not offer a privileged way to engage with this complex spatiality (cf Peck, 2017a; Leitner and Shephard, 2020). Instead, we focus on the constitutive spatialities of urban territories and of the actors involved in urbanisation processes, including their transnational reach and flows, institutional formations and lived experiences (Massey, 2005; Halbert and Rouanet, 2014; Allen, 2016; Keil, 2017). This inspires new grounds for composing comparisons and building concepts across the wide diversity of urban experiences, able to start from the fragmented, dispersed and often divergent territorialisations of urbanisation processes rather than comparing "cities", or configuring an analysis within the conceptual architecture of "scale" (Schmid, 2018; McFarlane 2019). Amongst these possible starting points are the ubiquitous large-scale developments which characterise urban developments across the globe. Other such territorialisations might include urban corridors, satellite cities, territories of suburbanisation, territories of extended urbanisation, landscapes of infrastructure-led development (Murray, 2017; see Kanai and Schindler, this issue). As grounds for comparative analysis, then, large-scale urban developments provide scope to bring many different urban experiences into the process of conceptualisation.

On this basis, we outline the grounds for a systematic analytical conversation across three large-scale urban development projects in three very different contexts. Our cases are Lingang, Shanghai (one of nine planned satellite cities), the Corridors of Freedom project in Johannesburg (a linear transport-oriented development seeking to integrate the racially divided city), and Old Oak and Park Royal in north-west London (a new neighbourhood planned in relation to significant new interchanges of metropolitan (Cross-Rail) and national (High Speed 2) transport infrastructure investments). Initially, comparability rested on the shared features of large-scale developments - that they are multi-jurisdictional, involve long time scales, and bring significant financing challenges. As the comparative process unfolded, the terms of comparison, and the object of study evolved (Deville et al., 2016). Each development came into view as a specific transcalar 
territorialisation of a range of urbanisation processes and actors (Halbert and Rouanet, 2014). Comparing three development projects, then, we are able to interrogate, rather than take for granted, how the urban outcomes in each case were the result of engagements amongst different actors and institutions in the context of specific territorial regulatory formations. Our comparative practice opens conversations across the three cases, on generative grounds (Robinson, 2016), composing a comparison based on the shared features of urbanisation through large-scale development projects. This indicates the potential for building insights across a diversity of urban experiences without prejudging the wider frameworks within which these urban developments might be analysed. A comparative approach which does not prejudge the terms of analysis is also open to the diverse literatures of the different contexts being considered, potentially enriching the vocabulary of urban studies in each situation.

Based on our research, we find expanded ways to characterise the interests of state actors in urban development; we consider how the need to embed developments in local political contexts amplifies the role of residents and community-based groups in shaping outcomes even where political circumstances for engagement are not propitious; and we observe that the urban development itself is crucial to securing financing, through property taxation, enterprise taxes or planning gain, drawing attention to the "urban land nexus" as a shared feature of urban development (Scott and Storper, 2015). Of course, starting from the perspective of the urban as specific can also deepen and extend understandings of wider social processes, such as neoliberalisation and financialisation. We identify financialised actors as closely woven into the territorialised political formations of each development, responsive to regulatory contexts and developmental agendas. Working across divisions such as national contexts, north-south, or delimited "conjunctures", and drawing on theoretical repertoires and insights from different contexts, we seek to establish grounds for a comparative urban practice which can more effectively support global urban studies and advance an open approach to conceptualisation across diverse and divergent urban experiences. 


\section{Theorising urban development: From "variegation" to "specificity"}

The term, "variegation" was introduced by Peck and Theodore (2007, p. 733) as a "still inchoate but putatively alternate vision" to the "space-blind" (p. 765) "varieties of capitalism" analyses of the geographies of global capitalism. In this paper they suggested that thinking about "variety" in relational terms, informed by the spatial analyses of economic geography, draws attention to the "complex asymmetries and webs of connection that increasingly characterise the unevenly integrating global economy" ( $p$. 766). The "common matrix" of the contemporary capitalism system indexes the networked terrain across which varieties (or variegations) of capitalism are produced neoliberalisation, financialisation and imperialism (p. 766). Their "provisional" use of the term "variegation" was firmed up considerably in the suite of papers with Neil Brenner on neoliberalisation (most fully in Brenner, Peck and Theodore, 2010; also Peck, Brenner and Theodore 2009). This conceptual culmination of a long decade of work by the authors, together and separately, on policy circulations, scale and spatial differentiation, as well as neoliberalisation, has strongly influenced urban studies. "Variegation" has become an important way to conceptualise outcomes of widely circulating processes, strongly hybridised through path dependency and political contestation. These outcomes implicate and influence systemic processes (such as the rule regimes of international policy and economic regulation), contributing to what they have variously called a "syndrome", "arc" or "forest" of neoliberalisation (Peck, 2013, 2017; Peck and Theodore, 2019). The term variegation therefore marks a rich spatial analysis, indicating the relation between specific localised outcomes and wider systemic processes configured through connections, wider historical processes and transnational institutions and actors, which are articulated through particular contexts with distinctive historical pathways. 
The nuance of the analysis, and its relevance to the spatiality of contemporary policy and economic processes has made this now a conventional term, rather than a hesitant proposition. It has been used to expand insights into many aspects of urbanisation, from neoliberalisation (Gonzales et al., 2018), to financialisation (Aalbers, 2017) and gentrification (Forrest, 2016), for example. Criticisms have also emerged, though, including concerns that the "systemic" analysis prejudges that the hybridisations which might emerge through the complex socio-spatial dynamics of variegation inevitably form part of pre-determined circuits. The outcomes may instead be developmental, related to divergent state projects, such as party-led, state-capitalist/socialist or illiberal regimes (Wu, 2014; Parnell and Robinson, 2012). The overarching conceptualisation (arc, forest, syndrome) has also been called into question - why do the diversity of practices and policies referenced all belong to the term "neoliberalism", or form part of a process of neoliberalisation (Le Galès, 2016)?

For our study, comparing three large-scale urban development projects in quite different "contexts", with divergent political and regulatory arrangements, we were drawn to question the term "variegation" as a useful basis for thinking about urban development. Aspects of the analytical perspective this term implies remain relevant. There are a multiplicity of transnational circulations and actors, as well as institutions with different scales of operation involved in large-scale urban developments. Large developments are moments of institutional and policy innovation, as inspiration for designs, and solutions to the great challenges they present are sought - scoping for policy ideas, best practice and learning from other contexts are often central activities for those involved. Thus, they might be imagined to be hard-wired into "variegated" processes (Moulaert et al., 2003). Large-scale developments are certainly closely embedded in the wider circulations of urbanisation - which can provide some (genetic) grounds (Robinson, 2016) for comparing examples of such developments shaped by interconnected processes, even across very different contexts. 
The point where we part company with "variegation" as a way to think about the politics of large-scale urban developments (and urban development more generally) is that it is not clear, in each case, what the large-scale development is an example of. Are they contributing to the contradictory realisation of neoliberalisation, or wider neoliberalised governance transformations (Moulaert et al., 2003) even as many large projects are stalled, fail or turn out rather differently than imagined? In the three contexts we studied, the developments were implicated in transnational circuits of investment (including financialised investors), policy and design; they were bound up with significant institutional innovation and state rescaling; and they were embedded in political processes of engagement, contestation and mobilisation. But the aims, procedures and end points of each were divergent. In Johannesburg, a developmental initiative sought to bring low-income housing to central locations following a major Bus Rapid Transport (BRT) investment; in Shanghai, a state-led programme of economic upgrading to expand production of manufacturing equipment was kick-started by a new deep water port; in London, land value uplift associated with a major new transport hub was leveraged to secure the resources for extensive new housing provision as well as offices in a challenging "brownfield" site.

Our grounds for considering the three cases together rested on their shared features as large-scale developments: the long time frames, multi-jurisdictional co-ordination, and financing challenges. In this sense, our grounds for comparison were "generative", in that we composed a comparison based on these shared features to support concept development and to take forward analysis in a particular field (Robinson, 2016). Our early findings confirmed that these elements were present in each of the developments, and also that these issues of temporality, multi-jurisdictions, and financing, were productive for thinking across the three cases, yielding valuable comparative insights (Robinson, Harrison, Shen and $\mathrm{Wu}, 2021$ ). Building a comparison on the basis of shared features across diverse contexts opens up the possibility to attend to the widest possible range of urban experiences in building conceptualisations, moving beyond entrenched habits of parochial theorisation based on a restricted selection of contexts. Given the 
ubiquity of large-scale urban developments, this is a promising basis for inspiring a more global reach for theorisation of urban development politics.

In our study, the territorialisation of governance practices and political formations at the scale of the project (Pinson, 2009) became apparent in each case. Different elements of the state, a range of developers, financial flows, designers, visions, policy innovation, as well as engagement and contestation from residents and community-based mobilisation coalesced to frame a rich and multi-dimensional process of the production of a new space in each urban context. Thus, with the extensive spatial vocabulary of urban studies and geography we came to think of our cases, following Halbert and Rouanet (2014) as "transcalar" territorialisations, what they call, "transcalar territorial networks". The multiplicity of networks and actors, their differential reach (Allen, 2016), overlapping institutional configurations (Allen and Cochrane, 2007) and their composition in relation to a specific territorial regulatory regime (Schmid, 2015) were operative in producing distinctive outcomes. Thus, in response to the significant, shared challenges of large-scale developments each gave rise to bespoke "business models" (ways of making development possible), reconfiguring extant governance arrangements, securing financing from a variety of sources, including the urban land value and activities generated by the development itself, and managing the resident and wider public concerns and interests (Robinson, Harrison, Shen and $\mathrm{Wu}, 2021$ ). The outcomes are specific, distinctive even in their own immediate context, and can only be appreciated across the multiplicity of these processes and actors, as part of the production of (new) urban space, even as they are deeply entwined with global circulations of actors, ideas and practices, processes of global economic competition, financialised processes of investment, and long-term governance transformations.

Methodologically, our analysis involves attending to the specificity of each development. This is not to abdicate explanatory analysis and insights into wider or circulating processes or institutional configurations (cf Peck, 2013; 2017). It also does not produce incomparability - rather it launches opportunities for creative reflection 
and designing comparative experiments across diverse and even divergent cases. In this sense, we want to think analytically with the diversity of the urban. We are not simply seeking to "reveal" the "context-soaked heterogeneous form" of wider processes, which Brenner, Peck and Theodore (2010, p. 206) see as a limitation of governmentality approaches. We are offering neither a purely descriptive nor an empiricist approach although the fullness and inexhaustibility of the urban world will always be a source of surprise for the conceptualisations any observer must start with (Robinson, 2016). Rather, we insist that this multi-dimensional complexity is the form of the urban, of space, and that insights into processes of urbanisation (as opposed to capitalism, or neoliberalisation) can be generated on this basis (Schmid et al., 2018). More specifically, starting with three rich and specific cases of "transcalar territorialisations" of urban development, we find grounds for comparative analysis to re-build the concepts of urban development politics in a way that is open to a wider range of analytical repertoires and urban experiences.

\section{Transcalar territories of urban development}

\section{1. $\quad$ Comparing three large-scale urban developments}

At first sight the sizes of the three urban contexts in which our case studies are located may seem disparate but at a functional metropolitan region scale we can note that in 2015 they were home to, respectively, around 24.2 million (Shanghai Municipal Government), 15.2 million (Gauteng City-region) and 24.2 million (London's wider southeast region) - all very large urban regions by twenty-first century standards. Nonetheless, the cases stretch across three quite different contexts with very different processes of state formation, political systems and economic co-ordination. Working across political systems of bargained authoritarian (Lee and Zhang, 2013), late (if not

post-) democracy, and an emergent developmental democracy calls for complex comparative tactics. However, if insights on interconnected and globalised urban 
development practices are to avoid the parochial theorisations of earlier US-led models (Lauermann, 2018), it is precisely this diversity which needs to come into view - and which inspired our comparative analysis.

In considering divergent governance and financial systems across three different regions, we broaden the geographical and analytical horizons of Shatkin's (2017) Asiancentred insights, which significantly expanded the vocabulary of urban development politics through attending to the state-centred and often informalised political interests which frame the politics of land in large-scale developments in China, India and Indonesia. Bringing our three cases into comparison highlights the significant difference that divergent institutional and financial architectures make to the outcomes and potential of large-scale urban developments: metropolitan-wide financing supported longer-term developmental ambitions in Shanghai and Johannesburg, contrasted with the more speculative outcomes in London, based on short-term state financing through land value capture focussed narrowly on the territory to be developed (Robinson, Harrison, Shen and Wu, 2021).

In this paper, we expand our concerns to bring into view a diversity of actors and interests, institutions and practices which broaden the scope for conceptualisation of urban development politics, which we return to consider in the conclusion. We draw out three of the dynamic relations constituting the territorialisation of large-scale urban developments, each of which comes most strongly into view in one of our cases. Insights are then expanded through the other two, apparently divergent, cases. Thinking each case through the others has deepened and enriched analysis of all - and also opened up the possibility to build insights in urban studies from a wider range of experiences and contexts. We stage this encounter in the text which follows, initiating each section with a different case which had particularly inspired our analysis of the other two, which we then discuss in turn. 
We selected the specific cases for comparison in a two-step process. Firstly, we were eager to explore the potential of comparative analyses across apparently divergent contexts. Africa and China, seldom compared and both exceptionalised in urban studies in different ways (Parnell and Pieterse, 2016; Wu, 2020), were also our primary areas of long-term research and so were our starting points. We added in the UK context, where one of us was already working with community-based groups, as a "new" research area which would allow us to open up a North-South conversation which we felt was important to consider in decentring existing theorisation in urban studies. In each context, we selected cases of large-scale development which we were already familiar with. This meant that a complex comparative analysis of very long-term developments would be feasible within a relatively short time horizon (we had two years of funding) and that we could anticipate building deeply grounded comparative insights. As we were methodologically interested in thinking across diversity, we were pleased to select three varied developments which were very large-scale for each context. Our research methods included long-term collaboration with community-based organisations, participation in planning consultations, in-depth interviews with around 30 key informants per case study including developers, state actors and community-based actors, as well as extensive document analysis and review.

\subsection{State-citizen relations: embedding developments}

Johannesburg, to Lingang and London

The Corridors of Freedom (COF) transport-oriented development project was announced by former mayor, Parks Tau, in 2013. The aim of this large-scale and longterm project is to produce an integrated, 'people-centred' and compact city that responds to the legacy of segregated apartheid planning which relegated the poor to spatially distant and poorly serviced areas. It seeks to 're-stitch' the spatially divided and highly unequal metropolis and to transform neighbourhoods radiating outwards from 
the inner-city along newly installed or planned Bus Rapid Transit (BRT) routes. The focus is on incremental mixed-use brownfield development and increased housing densities directed at lower income households. (Harrison et al., 2019)

The Corridors vision was articulated by the Mayor and bound in with his personality (Interview ${ }^{2}$, State 6,2017 ) but, within the City administration, institutional direction came from the Department of Development Planning. (State 1, 2016). Although empowered through its control of the municipal budgeting process, this department was thinly capacitated, requiring both agile and (over-)committed staff input ("the people that are involved in the process are on the edge of burn-out like all the time" State 1, 2016). "Embedding" (Evans, 1995) the project within state institutions, across different levels of government, as well as with developers, was crucial to ensuring its success. The Department relied heavily on the interest and involvement of the private sector to supply housing units and business spaces at scale. But state actors also had to seed and sustain the legitimacy of the project among its citizens, including both the vocal and politically organised (largely white) residents living near strategic sites along the corridors, and poorer (mainly black) residents who were the Mayor's political base. In Johannesburg, there is considerable experience of well organised groups delaying and opposing developments (Developer 6, 2017). Given the positioning of the initiative at the intersection of state-led visioning processes, profit-led real estate development, and the interests and reactions of the different segments of a fractured society, there were inevitable tensions - exacerbated by pressure from the Mayor for rapid results and electoral benefits (State 6, 2017).

In a number of our interviews, consultants and city officials noted the hostility of residents to the proposed developments when they were initially presented in large public meetings, with residents accusing the officials of disseminating information rather than enabling effective participation (Consultant 1, 2017). Middle-class residents

\footnotetext{
${ }^{2}$ We cite our interviews in each study area according to the position of the information in that context (State, Consultant, Developer, Community).
} 
were mainly concerned with proposed increases in density - which they linked to crime, slums, and the loss of property value - and with new social housing close to their neighbourhoods. Poorer residents were mainly concerned with the livelihood benefits of new developments and there were ongoing tensions around the allocations of jobs (Consultant 3, 2016; Developer 13, 2017, State 1, 2016). Feelings ran high, leading officials to observe that, despite the political and financial pressure to deliver quickly, "it's at that time we came back to the Mayor and said listen this thing is going to go sideways if we don't do this properly and we need time to do this" (Interview, State 1, 2016). To prevent the project from being derailed, the city administration responded by strengthening participatory processes. The City's development arm (the Johannesburg Development Agency) was, for example, brought in to facilitate participation in the preparation of the precinct plans for the various segments of the Corridors. (State 6, 2016; Consultant 1)

In these processes, the City had to navigate a complex political terrain as the Corridors traverse very different socio-spatial contexts. Although the electoral base of the ANC administration was mainly black African, the City of Johannesburg has had to be careful not to alienate the white middle class that provided a substantial share of the fiscal base of the city and could voice its concerns volubly through the media and other channels (Beall, Crankshaw and Parnell, 2002). City officials entered into negotiations with residents' associations around density and the location of new development, and adjusted targets and plans (State 1, 2016). At crucial moments it was the Mayor's presence and intervention which helped to move the process forward in middle-class neighbourhoods (State 1, 2016). Political and personal ties connected the city administration to black African neighbourhoods, although to differing degrees. Organised neighbourhoods in politically influential townships such as Soweto and Alexandra, were able to command the attention of city officials, and influence investments towards their areas (Planact, 2018). There was far less embeddedness in other socio-spatial contexts along the Corridors. The coloured (or mixed race) communities of Westbury and Coronationville, for example, mainly supported 
opposition parties and felt alienated from the City administration (Planact, 2018). The group least connected is arguably made up by transnational migrants (renters and subrenters) from countries in Sub-Saharan Africa who provide no electoral advantage to the City and who lack the leverage of paying property taxes or having a vote (Laundau and Freemantle, 2009). There were nevertheless limited attempts by officials to "walk the streets" of migrant-dominated neighbourhoods to identify groups that were not formally represented (State 1, 2016).

Political changes led to a shift in the patterns of embeddedness and institutional priority. In 2016, the ANC lost control of the Johannesburg Metropolitan Council to a curious de facto coalition between the centre-right Democratic Alliance (DA), with a mainly white middle-class as its electoral base, and left-wing populist Economic Freedom Fighters (EFF), with its base among the black African poor. The DA base was largely opposed to densification near middle-class neighbourhoods while the EFF demanded direct investment in historically black townships rather than in the linking corridors (Harrison et al., 2019; Parker and Appelbaum 2020). The Corridors survived but with significantly reduced investment from the City. Recent political instability has brought an ANC-led administration back to power under a new mayor but the future of the initiative remains uncertain (Robinson et al., 2020).

The Johannesburg case drew attention to the importance of embedding large-scale projects in state-citizen/resident relations, and the different ways in which this is undertaken across different groups. This informed our analysis of the other two cases, including Lingang where we had not initially envisaged the possibility for comparative insights on community engagements.

The 'developmental' ambitions of the Johannesburg case draws attention to the developmental goals of the Shanghai case, in terms of both economic upgrading and ambitions for social development. On the one hand this is to do with the importance of Lingang in the broader municipal economic growth agenda of industrial restructuring 
(as with the role of the Corridors in the broader spatial restructuring of Johannesburg post-apartheid). But the developmental state has also to attend to its embeddedness in a broader dynamic of support from the local population. Socially, Lingang was a relatively under-developed and remote area with a rural population. How to acquire land and resettle the existing rural population swiftly and peacefully was one of the first tasks officials had to address (Wang and Wu, 2019). The strategy was to make 'good' arrangements for local peoples' livelihood if possible; with prescribed relocation compensation, including apartments of $40 \mathrm{~m}^{2}$ per person in relocation settlements and state pensions for retired residents (Senior planner Lingang Group, June 2016). Lingang's approach to dealing with local residents followed the common resettlement logic that resettlement can bring prosperity to residents through generous compensation. $A$ senior official at LDMC described the resettlement process in Lingang as follows:

\footnotetext{
"Actually all the four townships are quite supportive of the demolition and relocation, because the residents also want to be relocated. As they say, a farmer's fate can only be turned around with demolition and relocation (农 民翻身靠拆迁)” (LDMC senior official, August, 2016).
}

The township governments were tasked with informing and resettling residents, since township officials were familiar with the local situation and the needs of residents. To ensure a smooth transition for residents to their new housing, Lingang initially prioritised the development of relocation settlements and public amenities such as schools and hospitals over the development of commodity estates. Efforts were also made to ensure that township governments benefited since the state relied on townships to deal with dissatisfied residents. Through allocating parcels of industrial park land to township governments to develop to the benefit of local communities, Lingang sought to bind township governments and local residents into the development. Both the institutional formation and the physical development were shaped by the need to embed the development in local social relations. 
However, following the completion of the initial phase of development which included land-intensive developments such as highways and roads, the demand for more land and thus resettlement decreased significantly. Additionally, at the same time as the industrial development slowed down, legislation was changed and prevented the acquisition of development loans against land which is yet to be made vacant (Senior official at LDMC, August 2016). The slowing down of the resettlement process resulted in controversial and tense moments in relations between residents and the municipal and district bodies, and the State Owned Development Corporations (SODCs). When relocation from rural villages was halted, some were left living in now deserted underserviced settlements, many dependent on housing migrant workers and adjacent to industrial zones with significant pollution hazards (Wang and Wu, 2019).

Although the two cases of Johannesburg and Shanghai indicate that state-community engagements have actively shaped the outcomes and governance of large-scale developments, dominant analyses in urban studies have been informed by researchers focussed on places such as London, emphasising "post-politics" and constraints on community engagement in urban development processes (Swyngedouw, 2005; Raco, 2014; Lees, 2014). Participation, often led by developers, is understood as providing only the semblance of openness, while the hidden face of power proceeds in technical and restricted forums (Drozdz, 2014); participation is seen as simply complying with the agendas of power (Swyngedouw, 2011). Our comparative research led us to different conclusions. From the Johannesburg case, we were alerted to the challenges of "embedding" support across diverse and conflicted constituencies, and from Shanghai we were also aware of how state-resident interactions changed over time as the development progressed. On this basis, we were able to critically reflect on Swyngedouw's (2005) sense of the dual "Janus" face of urban development politics in London to identify several different settings in which residents' participation was sought. Rather than a cynical dualism, we noted that residents were able to engage to varying extents. In some settings their inclusion was crucial to the project's progress and their ideas and insights were valued; on other occasions they (and other actors) were 
either directly excluded from engagement with planning and decision-making, or the terms of engagement were decidedly onerous.

Settings for early policy development were open to resident's perspectives and concerns, both those within the development corporation area (c.1500 houses) and those in neighbouring areas. Planners for the Old Oak Park Royal Development Corporation, tasked by the Mayor of London with bringing forward the development, sought to draw on residents' local sense of place to inspire plans. They responded to residents' concerns and early proposals identified sensitive areas on the edges of the development where development would be restricted to protect existing residential neighbourhoods. Funding for a place-making initiative focussed on the Park Royal Industrial area drew in many residents from the affected areas. However, the lengthy and intensive planning policy process and some early developments saw statecommunity relations experience many twists and turns. "Sensitive edges" where tall buildings were to be restricted were replaced by provisions for dense high rise early developments. These were intended to generate profit and increase planning gain incomes to fund infrastructure. Policy visions morphed into versions that read like developer briefs in which many good ideas shared between planners and communities became merely possibilities which might be funded if enough profit was generated from the development: social infrastructure, affordable housing, and key transport investments were all to be largely funded from planning gain contributions from development (Robinson and Attuyer, 2020).

This directs our attention to a different setting: routine behind closed-doors negotiations which took place between planners and developers about design and developer contributions to planning gain, to identify how trade-offs could be made across different priorities for the development. In fact, both parties collaborated to maximise income from the development while navigating planning policy commitments and design requirements. Residents' concerns were only presented in these settings indirectly via the planners, who were under pressure to prioritise infrastructure and 
housing delivery (Robinson and Attuyer, 2020). For the OPDC, securing the financing for the development ( $£ 2.5 \mathrm{bn})$ is a major challenge, and developer contributions will not be enough. So, in yet other settings, where the OPDC's role is to bring forward developments through its own development arm, even more secret activities were undertaken. A masterplanning process excluded both communities and developers from negotiations with central government in an attempt to secure some additional infrastructure financing $(\mathrm{f} 250 \mathrm{~m})$. These later activities reflected a decline in the participative and collegial approach which had, from the perspective of some, shaped the first years of the OPDC practice (Community Representative 2 and 3,03/08/2016).

Inspired by the Johannesburg case, our assessment is that focusing on the varied settings for public engagement can identify specific areas of democratic deficit and indicate how community based organisations might take forward a targeted political programme to expand voice and equality (Drozdz, 2014). This could promote political opening rather than focusing on the closure identified in post-political analyses (Swyngedouw, 2005). More generally, in contexts like South Africa (Brown, 2015), Brazil (Holston, 2011) and India (Patel et al, 2012), achieving political gains, even incremental ones, builds on patient processes of mobilization, engagement and institutional transformation - drawing the state to embed the development through territorialized community agency. In Lingang, and China more generally, residents' mobilisations have secured sharing of benefits through compensation, and also contributed to shaping the complex institutional arrangements needed to bring forward the development (Hsing, 2010; Shen et al., 2020).

\subsection{Intra-state: assembling transcalar state agency}

Lingang to London, and Johannesburg 
Lingang is a municipal mega urban project, which demonstrates the significant role of the local state. However, the actual delivery of Lingang has been achieved through various municipal and district development corporations. To involve local communities, at the township level, smaller industrial zones and development corporations have also been set up. In other words, the development has been carried out by an assemblage of development corporations across different scales (Shen et al., 2020). All these development actors are 'state-owned' but the actual ownership is scattered across different levels of government. For Johannesburg, the difference is that the COF development is led directly by the state institutions rather than by a dedicated municipal agency or development corporation. For London, the state-owned development corporation had no guaranteed income or land assets, and relied closely on negotiating with private sector developers. In Lingang, the development corporation operates under the guidance of the government (specifically the development management committee, guanweihui). This is a distinct model in China, allowing the enterprise to borrow financial resources independently, although there are close linkages between the development corporation and local government. In Lingang, the management committee and development corporation have 'two names but one set of personnel' (liangkuai paizi, yitao renma). This approach reflects state entrepreneurialism $(\mathrm{Wu}, 2018)$ which uses the 'market instruments' but subject to the planning and developmental centrality of the state. These instruments include development corporations and 'land backed mortgages' (Wu, 2019).

The Lingang project began in 2002 with the Shanghai municipality's ambition to develop China's largest deep-water harbour. The Shanghai municipality convinced the central government to assign Yangshan island from Zhejiang province's jurisdiction to Shanghai with the prospect of developing China's first deep-water harbour and to compete with other countries already in possession of a deep-water harbour including Singapore and South Korea. The municipality felt that a harbour city would provide important support services such as logistics, for the Yangshan deep-water harbour (Lingang senior planner, June 2016). Yangshan harbour in turn would help Lingang become a harbour city 
equalling the success of Hamburg Hafen City or Alexandria (GMP Architect, June 2016). The development of Lingang was motivated by a second reason, namely to help Shanghai upgrade its industrial sector to include the heavy equipment manufacturing industry. The final vision for Lingang was thus as a combination of harbour city and a large industrial zone specialised in heavy equipment manufacturing.

Rather than relying on private capital and developers, however, the Shanghai municipality instead relied on a set of state agencies to deliver Lingang. State owned development corporations took on the role as the primary developer and were given starting capital from the Shanghai municipal government to acquire land from rural residents and to develop the land according to the vision set out by Lingang's masterplan. Initially, there were two development corporations. Lingang Group is in charge of the heavy equipment manufacturing zone and focused on attracting heavy equipment companies to Lingang. Harbour City Group is responsible for developing the main town of Lingang and attracting residents to develop Lingang into a vibrant harbour city with a planned population of 800,000 residents. Moreover, the municipality created the Lingang Development Management Committee (LDMC) to take over planning responsibilities and to examine and approve specific developments of Lingang. Relieved of their planning and development responsibilities, the district government of Nanhui (later replaced by Pudong district) and the township governments are tasked with governing the local population of Lingang including handling the process of resettling rural residents, dealing with resident complaints and managing the life of residents after their resettlement.

According to the Shanghai municipality, the institutional set up of Lingang makes optimal use of the specialised knowledge of different state organisations. Lingang's two SODCs and the LDMC are all headed by seasoned managers and planners who have successfully delivered previous state projects and have the necessary development and economic expertise. The district and township governments with their abundant knowledge of the local population are much better suited to deal with residents. The 
assemblage of development agencies and actors reflect the nature of the project as a developmental mission for Shanghai. For Lujiazui Group, another major SODC which was tasked by the municipality to develop in Lingang in 2009, rather than a project focused on short-term profits through real estate development, Lingang is:

"a political mission so we accomplish it...There has never been a case where the Lujiazui Group could not deliver just because the economy is not doing well" (Lujiazui Group senior planner, August, 2016).

In London, the analysis of the Lingang case focussed our attention on the multiple roles of the state - as policy maker, regulator and development manager, as well as developer. Analytically this insight was highly significant in allowing us to critique the popular London discourse of powerful global developers overwhelming weak local state actors unable to defend public interests (Colenutt, 2020; Robinson and Attuyer, 2021). Unravelling the multiple interests of state actors drew attention to the continuing power of the state to extract planning gain income, in a context where other sources of funding for development had been constrained. We discuss this further in the following subsection. Some aspects of state interests have therefore become closely aligned with those of developers; but other interests are also evident - exposed by attending to the multiple roles of the state in urban development. This is reflected in our analysis of the diverse settings of community engagement (above), where different planning rationalities (and different planners) were operative in the different settings. In addition, as in Lingang, despite the creation of a bespoke development corporation, a wide range of state agencies and actors had to be drawn together around the territory of the project to secure its delivery. In London this related strongly to the search for a viable business model for the development. With few resources available to pay for infrastructure, and a highly fragmented political system (Travers, 2004), the need for collaboration across jurisdictions was apparent from the beginning as the core development area cross-cuts three London Boroughs. As with many large-scale developments, this jurisdictional complexity presented numerous challenges. Thus, the opportunity was seized to draw 
on a new competency for the GLA (since 2011), to create "Mayoral Development Corporations", and the OPDC was created on 1 April 2015. Concerns are often expressed about the institutional capacity of local boroughs to manage such huge developments (Interview, GLA Officer 1), and large-scale developments in London (in "Opportunity Areas") do anyway usually proceed through collaborations between the Mayor's regeneration teams and local boroughs. Establishing a formal Development Corporation to take over planning powers from the three boroughs, with representation from each borough on the Board and the planning committee, provided a new way to navigate the relationships amongst the GLA, OPDC and the three London boroughs.

Complexity also characterised the relations with national state agencies. The train infrastructure operator, Network Rail, and the Department for Transport are major landowners in the OPDC area, as well as responsible for the land along the proposed HS2 high speed train tracks. Their development interests are overseen by a wholly stateowned property developer, London and Continental Railway, whose strategy, honed in relation to the HS1 (channel tunnel) project, involves seeking to maximize value of their property assets through land sales. Despite an early "Memorandum of Understanding" (2015) to work together with the Mayor on the development of these lands, the reticence of the public sector bodies to yield on achieving maximum value for their land means their redevelopment has been pushed into the very long term, largely beyond the twenty-year period of the draft local plan. This has increased early development pressure on other sites in the project to generate finance for the development.

In sum, then, a new institutional model of the Mayoral Development Corporation has re-scaled planning and development authority away from the local boroughs to the Metropolitan authority ${ }^{3}$. But the operations of the OPDC are dependent on convening a transcalar alignment of state and non-state actors and interests in relation to the

\footnotetext{
${ }^{3}$ We acknowledge the helpful observation of one of the referees for this paper that in some aspects our approach varies from that of Peck and Theodore (2007) as we are concentrating on a different "scale", the development project. We prefer to use "scale" here in an ordinary language sense rather than theoretically freighted; our insights emerge in relation to a different spatial imagination of transcalar territorialisations.
} 
specific territory of the development. This entails co-ordinating complex intragovernmental relationships, from very small local boroughs to a weakly capacitated metropolitan Mayor, as well as powerful national state agencies and central government departments.

In Johannesburg, the Corridors of Freedom was an ambitious project for the city administration and, as in London, the challenge was to influence actors operating across different scales, within and outside government, to direct their actions in support of the vision. The relational capacity required for the project came from constructing different forms of embeddedness, including within state-citizen relations, as discussed above, and within a complex matrix of inter-and intra-governmental relationships. In one respect, Johannesburg had a significant advantage over London as the city administration was constructed in 2000 at the end of a post-apartheid transition, as a single-tier metropolitan authority. There was no need for the metropolitan authority to negotiate the project with local authorities or to construct a body such as a development corporation that could manage across local and metropolitan functions. However, the City of Johannesburg was still a complex organisation, incorporating multiple departmental and political interests and requiring mechanisms for cohering city-level action. The personal authority and institutional power of the executive mayor was an important factor but so was the technical control that the planning department exercised over the budgets of other internal agencies.

Beyond the city, implementation required the support of other spheres of government. The National Constitution adopted in 1996 protects local government but also frames it within a complex system of inter-governmental relationships. The Corridor had an unexpected challenge from a coalition of interests within government that linked the agenda of the national Minister of Housing to promote 'mega' housing projects on the peripheries of urban areas, to the spatial agendas of Provincial Government, and with segments of the property industry. This was contrary to the vision of the city administration to consolidate development and densify along centrally situated 
transport corridors and detracted from the overall priority of corridor-type development across government. However, the Corridors initiative was protected by the near fiscal independence of the City of Johannesburg, the support it received from the powerful National Treasury, and the fuzzy means of accommodation between city and provincial governments which allowed both to pursue their own visions with apparent support from the other but this fragile inter-embeddedness left the Corridors programme somewhat exposed to political change at city level. (Ballard et al., 2017)

In all three cases the projects initiated a reconfiguration of state institutions, territorialising capacity across different agencies and actors. Thus, we identify the transcalar territorialisation of state agency as a key feature of all three cases, necessary to bring forward development.

3.4. Developers and territories: Navigating institutions, fixing flows of finance

London to Johannesburg, and Lingang

In London, development is reliant on the private sector and is brought forward through complex mutual negotiations between the state and developers. The OPDC case highlighted most strongly the formative nature of the financing arrangements for development outcomes. Crucial here was the high cost of development in an area with difficult terrain and poor infrastructure; the land ownership structure also meant that this was not an area which had a naturally high visibility or attractiveness for developers. Analyses of property and housing development in London have focussed on the agency of global investors - a speculative wall of money pressing on the London landscape to which local councils had little response (de Verteuil and Manley, 2017; Fernandez et al., 2016; Colenutt, 2020). But as with all three of our cases, our study of the Old Oak Park Royal development showed that (transcalar) state agency was closely involved in drawing in investment and finance, and strongly shaped the nature of the developments 
brought forward by financiers and developers. This included pressing for early progress on the edges of the area, which produced a predominance of rental-based developments as sales values would be depressed during the lengthy construction phase. Moreover, the developers who were motivated to invest in the OPDC area had a range of origins and transnational reach, and varying interests in the land development.

The question of value is crucial for the developer, but, as we noted, for the planning authority too. The OPDC was looking to maximize value capture over the life of the project to fund the costs of delivery. This had to be secured during a narrow window of opportunity to negotiate planning gain contributions from the developer at the site and moment of construction (Robinson and Attuyer, 2020). In addition, the funding streams for the state - both S106 and CIL charges ${ }^{4}$ - relate directly to the height and density, and thus the quantum and profitability of developments. The negotiation process between planners and developers, in regular meetings over a period of 2-3 years, is where these issues find settlement in a determinate built form which has to meet a range of policy agendas while keeping the developer on board. As one developer noted, "well, you know, we've got our exit strategies and you know you just weigh up the risk" (Property developer 6).

Between the competing objectives for developments to realise developer profits as well as meet the Mayor's targets for housing, contribute to financing infrastructure and deliver planning policy obligations, architects can struggle to meet professional norms or market demands for high quality design. At times they even worked against the planners, to decrease height and density (Architect 4, 30/08/2016). Developers were pragmatic about the planning processes which underpinned determining planning gain and policy obligations in London, and made sure that their teams were composed of locally experienced people (Property Developer 3). Locally embedded reference points

\footnotetext{
4 "The Community Infrastructure levy (CIL) is a locally determined fixed charge on development which usually takes a relative form, such as ' $£ X$ per square metre of new development'." (Ministry of Housing, Communities and Local Government, 2018, p. 6). "S106" contributions are based on bespoke agreements on planning gain, negotiated on a development by development basis.
} 
were therefore important to (global) architects and developers, as they were to the local planners. In searching for "best practice" cases to inspire development, the planning authority and their consultants drew overwhelmingly on London-based cases and precedents (OPDC, 2018). It is in this context that reports from several developers that planners had encouraged them to build higher densities and heights than envisaged, as well as the paradoxical push from the major developer to lower the quantum and densities, can be understood.

However, value propositions varied considerably amongst developers. For a number of developers their starting point in negotiations was to look to maximise the envelope for building: "the first thing you do on an application is the bulking exercise. You, first go for bulk. The developer always goes for maximum bulk and the planners will pull him back and then you reach a happy medium" (Property developer 3 ). For others, the difficulty was to gain planning approval when they were unwilling to build as high or to such densities as the planners wanted. This is particularly relevant in relation to financialised investors, such as global pension funds, seeking to mobilise the built environment as a liquid asset, yielding long term, secure returns to investment through bespoke rental properties. Here developers struggled with the high land values and the need to keep buildings to a standard height and format according to the investor model. In one case, local planning authorities, including the OPDC, found little traction to press financialised international developers to build higher, to extract further value from the development, leading to an impasse (Ealing Council Planning Committee, 3 February 2016). However, more flexible combinations of developers with conventional construction financing and London-based housing associations leveraging their social housing assets and with significant housing management experience enabled the build to rent model to come forward in a more dense format, according to very rapid time scales compared with "build to sell" properties. The ability for this model to meet the growing backlog of houses for both middle class and low-income groups across London has informed the Mayor's enthusiasm for BTR in his wider housing policy, as well as in the approach of the OPDC (Mayor of London, 2018; OPDC Officer 1, 06/02/2018). 
The need to find alignment between developer and state interests in the London case was particularly acute, but led to tensions. There was nonetheless considerable overlap in their interests to build more densely and higher to achieve enhanced returns, while also needing to ensure locally applicable planning policy norms were not undermined to the detriment of either elector confidence or market interest. We see, then, a territorialised co-ordination of regulatory processes in relation to this specific project as well as the emergence of negotiated relationships between states and developers which enabled investors with a range of different interests, and spatial reach, to co-produce and navigate the arrangements needed to enable the development to proceed. This confirms our theoretical approach to the urban as distinctive, and the methodological commitment to building insights about large-scale developments, including the financing of urban development, across diverse urban contexts.

In Johannesburg, the territorial foundations of transnational financial flows and actors are evident, as specific concerns and path dependent trajectories influenced both state and developer financing. The overall financing of the Corridors Project in Johannesburg was secured through intra-municipal co-ordination of routine income streams, largely property-based taxes and profits on utilities, as well as loan income (municipal bonds and a developmental loan from the French AFD). But, as in London, to secure the housing development which the project envisaged required the capacity of the state to influence patterns of real estate investment, and this remains critical to the success of the Corridors initiative. The corridors are not 'natural' territory for most developers who have focussed their developments mainly in the affluent northern parts of the city. Hence the municipality has attempted to induce developers to invest in the corridors, and to invest in ways that meet the specific objectives of the initiative. As Todes and Robinson (2019) explain, the outcomes are uncertain with varying levels of interest from different segments of the real estate industry. The Corridors initiative has largely drawn on a newly emerging sector of developers focused on the affordable rental and student housing market, extending a local model where derelict inner city buildings have been 
redeveloped as secure, tightly managed accommodation offering small well-located units for the lower-middle income market (Mosselson, 2016). This sector began with small developers and social housing institutions responding to an undersupplied market, in a context where large financial institutions had hardly invested in rental housing for decades but has extended to include financialised investors through, for example, the establishment of a residential REIT, the entrance of an international social impact investor into the market, and the creation of the Trust for Urban Housing Finance (TUHF) to support small developers (Financier2, 1/9/2016; Nurick et al, 2018; Todes and Robinson, 2019).

The Corridors are beyond the main areas where inner city developers operate but became more attractive as property prices in the inner city have increased. Diverse small local developers, some of whom were already involved in affordable rental housing or the student market in these areas, have been attracted to new opportunities. Larger firms focused on the affordable housing market have expressed some interest, but their developments have so far remained confined to the edges of the Corridors where larger land parcels have been available ( Developer10, 31/8/2016; Developer12, 22/11/2016).

The municipality has offered some inducements to enable development, in addition to infrastructure development: rates rebates; relaxation of regulations to allow and encourage higher density development; and promises to simplify and speed up approvals processes. The City also proactively assisted developers by generating design approaches appropriate to the Corridors (small spaces including social facilities), using consultants to develop financially viable models for low-income rental, and by partnering with the TUHF to facilitate financing for developers. There were however differences between city planners and developers over matters such as density levels and rental charges, with officials pushing for higher densities to support the BRT and lower rentals to ensure inclusion (State 2, 1/3/2019). 
In Lingang, as in London and Johannesburg, financing and development drew on existing practices but also had to respond to the challenges of the development with innovations. The project was initially financed through a combination of a starting capital from the municipality and through land-based financing from banks ( $W u, 2019)$. The starting capital and bank loans were mainly used to resettle rural residents living in the industrial zone of Lingang and to develop basic infrastructure including roads, bridges as well as industrial space to be sold or rented out to businesses. The cost for developing the main town was lower than the industrial zone since all of its land was acquired through land reclamation and thus did not require expenses for compensating resettled residents. Subsequent income streams mainly came from the heavy equipment zone including from land leased to firms and factories moving to Lingang and their business taxes. However, income from the industrial zone was far from enough for the development to break even, given the substantial investment in transport infrastructure. Revenue from land sales for residential developments fell short. This was partly as the industrial zone and the deep-water port needed fewer staff due to automation, and partly as Lingang is considered too remote and lacking the vibrancy of a city, so those staff working in Lingang preferred commuting back to the city. Conversations with senior officials reveal that Lingang's current income is only sufficient to cover its running expenses but cannot recoup its initial investments. For this reason, when asked about why the project never considered relying on private developers to deliver Lingang, a senior planner from a SODC explained that private developers are too focused on making short-term profit and were not to be trusted with generating the sustained revenue a large and strategically important project such as Lingang required (Lujiazui Group, July 2016).

Instead, while Lingang's focus over the past decade has been on attracting more residents through increasing the urban functions and activities in the main town, the municipality directed Pudong district's four biggest SODCs to invest and develop in Lingang's main town under the motto of 'leading the army southwards, for the final battle in Lingang' (挥师南下, 决战临港). Private developers played a more minor role. 
The LDMC and Harbour City Group sought to attract private developers for some of the attractions, including an Ocean Park developer (see Shen et al., 2020 for further details) and major housing developers including Vanke and Greenland were brought in for small scale developments to increase market confidence in Lingang. However, similar to both the Corridors project and the OPDC development, Lingang is not a 'natural' territory for private developers. In this case, this is due to its remote location. Private developers only joined the development following generous subsidies from Lingang. For instance, Vanke only agreed to develop in the main town when Harbour City agreed to share the risk of investment by owning $49 \%$ of shares of the business venture and sold the land to Vanke at a very low price (Vanke Lingang branch manager, June 2016). Yet despite the government's support, Vanke only developed what the company considers as a small to medium project that requires little investment, has a short time frame and yields fast return (短本快). Further financial support from the municipality came in the form of the 'double special' (双特) policy. The policy allows Lingang to keep the share of tax income that normally needs to be paid to the municipality and the district government. Lingang Economic Group also invested in residential development projects in other places to subsidize this municipal mega project.

Across all three cases the projects relied on a diversity of developers and financing mechanisms. Specifically, in each case we have seen that a territorialisation of developer-state relations and a bespoke financing solution relying on resource flows from the development itself (as property or enterprise tax, or as planning gain) effectively co-produced a distinctive approach to value and built form in each project.

\section{Conclusion: Conceptualising urban development politics}

Our comparative analysis has demonstrated that large-scale urban developments are shaped by strongly path dependent regulatory contexts, and also result in a specific territorialisation of political institutions and actors. Theorising from specificity, we 
suggest, has the potential to rebuild insights on the nature of the politics of urban development across different and divergent contexts. This will require patient and open re-construction of concepts, emergent from different urban experiences. From our study, we are able to identify some features of urban development politics which could speak across the different contexts, allowing us to learn from one context to another, and inspire further interrogation. Our approach, which explored the territorialisation of political processes at the scale of the development project, is potentially especially relevant at a moment when urbanisation has become delinked from the territories of municipal government, and is rather extended, fragmented and dispersed across regions, corridors and transnationally.

We focused on the dynamic transcalar relations (state-citizens; intra-state; statedeveloper) which are emergent in the course of large-scale developments, and which coalesce as distinctive territorialisations of urban politics. First, we were inspired by the Johannesburg case where electoral and fiscal dependence required considerable efforts to embed the development in local political relations. We noted in all three cases how the state is drawn through the territorialized agency of residents to shape, in different ways, aspects of the development, its governance (including seeking to exclude residents), design and social impacts. Future research might explore the different ways in which electoral systems, questions of legitimacy (based on development, participation and/or bargained relations of quiescence), and different forms of planning reason contribute to urban development processes.

Second, in all three cases the projects initiated a reconfiguration of state institutions, territorialising capacity across different agencies and actors at the scale of the project to bring forward developments. These sought to meet different goals both developmental and competitive - economic upgrading, (social) housing needs, or general urbanisation. The interests of state actors, and competition amongst them, are an important aspect of urban development politics. In the projects we studied these were closely bound up with the value generated by the development, through general 
or property taxation, profits on direct development activities, or land value capture of some kind. Thinking across a diversity of political systems highlighted the urban basis of state agency, in land and in broader urban development goals, which deserves further investigation.

But other actors were also crucial to the delivery in each case. The processes of territorialising flows of finance and the agency of transnational developers strongly shaped development outcomes. Thus, third, the projects relied on a diversity of developers and financing mechanisms. So, state institutions worked to reshape developer practices to encourage responses to challenging or unfamiliar circumstances, and to ensure that the resources for the project could be generated, and the desired outcomes realised. A territorialisation of developer-state relations effectively coproduced a distinctive approach to value and built form in each project - suggesting that rather than tracing variegated processes of financialisation and their hybridisation, analyses of the emergent, urban bases of development financing could be insightful. Nonetheless, we are also able to draw insights about the nature of the wider process of financialisation. In both Johannesburg and London, financialised investors were drawn into territorialised configurations oriented to delivery of more developmental outcomes: a locally distinctive format of low-income housing in Johannesburg; and addressing a politically determined priority for significant expansion of well-managed (although not low-income) rental housing in London. Our comparative analysis therefore offers insights to nuance conclusions regarding the politics of financialised urban development (Beswick et al., 2016; Aalbers, 2017; Rolnick, 2018). More generally, comparative insights can enrich or critique understandings of wider processes; while developing comparative analyses from the perspective of the urban as distinctive, or specific, opens the possibility of identifying alternative processes as relevant. In this case, we noted that financing (rather than financialisation) was closely dependent on the regulatory context and the specific configuration of the development project. 
The construction of new urban territories results in the constitution of forms of highly specific territorialised political relations. How these are configured varies, but across divergent contexts bringing forward large-scale developments involves the production of specific political and institutional configurations over long time horizons, across multiple jurisdictions and with an array of transnational processes and actors. To understand these, we have suggested that closer attention needs to be paid to the dynamic processes involved in negotiating political relations with residents (embedding projects), redirecting and influencing developers and investment flows (generating finance), and re-organising state institutions and interests (configuring institutions).

Starting to rebuild analyses of urban politics across diverse and divergent contexts is a crucial task for urban studies. We have proposed one way forward for this, assessing that the form of urban politics is not so much variegation of (well-known) wider processes, or the delimited perspective of contiguous "conjunctures" (Leitner and Sheppard, 2020), but rather emergent and specific transcalar territorialisations, possibly in far flung and dispersed urbanised territories. On this basis comparative analysis can enable the actors and processes involved in urban development to be interrogated on their own terms and across a diversity of urban contexts. The dynamics which we have identified here - state-community embedding; intra-state co-ordination at project scale; and developer-state collaboration - offer possibilities for grounding future enquiries in urban development politics.

\section{Funding}

We acknowledge funding from the ESRC for an Urban Transformations grant ES/N006070/1, "Governing the Future City: A comparative analysis of governance innovations in large scale urban developments in Shanghai, London, Johannesburg. 


\section{Acknowledgements}

We would like to thank all those who agreed to be interviewed and who supported our engagement in the three developments. We also thank those who worked on the project with us, notably Allan Cochrane and Margot Rubin. In London we thank Sharon Hayward of the London Tenants' Federation, Robin Brown together with others at Just Space; and members of the Grand Union Alliance and Old Oak Neighbourhood Forum. And in Johannesburg we acknowledge the partnership and engagement of Planact, especially Mike Makwela. In Shanghai, Prof Yuemin Ning of East China Normal University was an intellectually inspiring and most helpful host for project activities whose close knowledge of the Lingang case shaped our research questions and informed our analysis from the beginning. We also gratefully acknowledge the support of the South African Research Chairs Initiative of South Africa's National Research Foundation. We acknowledge funding from the ESRC for an Urban Transformations grant ES/N006070/1, "Governing the Future City: A comparative analysis of governance innovations in large scale urban developments in Shanghai, London, Johannesburg.

\section{References}

Aalbers MB (2017) The Variegated Financialization of Housing. International Journal of Urban and Regional Research 41(4): 542-554.

Allen J (2016) Topologies of Power: Beyond Territory and Networks. London: Routledge.

Allen J and Cochrane A (2007) Beyond the Territorial Fix: Regional Assemblages, Politics and Power. Regional Studies 41(9): 1161-1175. 
Ballard R, Dittgen R, Harrison P and Todes A (2017) Megaprojects and urban visions: Johannesburg's Corridors of Freedom and Modderfontein. Transformation, 95: 111-139.

Beall J, Crankshaw O and Parnell S (2002) Uniting a Divided City: Governance and Social Exclusion in Johannesburg. London: Routledge.

Brenner N (2005) New State Spaces: Urban Governance and the Rescaling of Statehood. Oxford: Oxford University Press.

Brenner N (2019) New Urban Spaces: Urban Theory and the Scale Question. Oxford: Oxford University Press.

Brenner N, Peck J and Theodore N (2010) Variegated neoliberalization: geographies, modalities, pathways. Global Networks 10(2): 182-222.

Brenner N, and Schmid C (2015) Towards a New Epistemology of the Urban? City 19(23): 151-182.

Brown J (2015) South Africa's Insurgent Citizens: On Dissent and the Possibility of Politics. London: Zed Books. 
Choplin A and Hertzog A (2020) The West African corridor from Accra to Lagos: a megacity-region under construction. In: Labbé D and Sorensen A (eds.) Handbook of Megacities and Megacity-Regions. London: Edward Elgar, pp.205221.

Colenutt B (2020) The Property Lobby: The Hidden Reality Behind the Housing Crisis. Bristol: Policy Press.

DeVerteuil G and Manley D (2017) Overseas investment into London: Imprint, impact and pied-à-terre urbanism. Environment and Planning A 49(6): 1308-1323.

Deville J, Guggenheim M and Hrdličková Z (eds.) (2016) Practising Comparison: Logics, Relations, Collaborations. Manchester: Mattering Press.

Drozdz M (2014) Regeneration b(d)oom: Territoires et politique de la régeénération urbaine par projet á Londres. PhD Thesis, Université de Lyon II, France.

Evans P (1995) Embedded Autonomy: States and Industrial Transformation. Princeton, NJ: Princeton University Press.

Fernandez R, Hofman A and Aalbers MB (2016) London and New York as a safe deposit box for the transnational wealth elite. Environment and Planning A 48(12): $2443-2461$. 
Forrest R (2016) Commentary: Variegated gentrification? Urban Studies 53(3): 609614.

González S, Oosterlynck S, Ribera-Fumaz R and Rossi U (2018) Locating the global financial crisis: variegated neoliberalization in four European cities. Territory, Politics, Governance 6(4): 468-488.

Goonewardena K (2018) Planetary urbanization and totality. Environment and Planning D: Society and Space 36(3): 456-473.

Halbert L and Rouanet H (2014) Filtering Risk Away: Global Finance Capital, Transcalar Territorial Networks and the (Un)Making of City-Regions: An Analysis of Business Property Development in Bangalore, India. Regional Studies 48(3): 471-484.

Harrison P, Rubin M, Appelbaum A and Dittgen R (2019) Corridors of Freedom: Analyzing Johannesburg's Ambitious Inclusionary TOD. Journal of Planning Education and Research 39(4): 456-468.

Holston J (2007) Insurgent Citizenship: Disjunctions of Democracy and Modernity in Brazil. Princeton, NJ: Princeton University Press. 
Kanai JM and Schindler S (2019) Peri-Urban Promises of Connectivity: Linking Project-Led Polycentrism to the Infrastructure Scramble. Environment and Planning A: Economy and Space 51(2): 302-322.

Keil R (2017) Suburban Planet: Making the World Urban from the Outside In. Cambridge: Polity.

Lauermann J (2018) Municipal Statecraft: Revisiting the Geographies of the Entrepreneurial City. Progress in Human Geography 42(2): 205-224.

Lefebvre H (1996) Writings on Cities [edited and translated by Lebas E and Kofman E]. Oxford: Blackwells.

Lefebvre H (2003) [1974]. The Urban Revolution. Minneapolis, MN: University of Minnesota Press.

Lefebvre H (2009) [1940]. Dialectical Materialism, Minneapolis, MN: University of Minnesota Press.

Le Galès P (2016) Neoliberalism and Urban Change: Stretching a Good Idea Too Far? Territory, Politics, Governance 4(2): 154-172. 
Lee CK and Zhang Y (2013) The Power of Instability: Unraveling the Microfoundations of Bargained Authoritarianism in China. American Journal of Sociology 118(6): $1475-1508$.

Lees L (2014) The urban injustices of New Labour's 'new urban renewal': the case of the Aylesbury Estate in London. Antipode 46(4):921-947.

Leitner H and Sheppard E (2020) Towards an epistemology for conjunctural inter-urban comparison. Cambridge Journal of Regions, Economy and Society 13(3): 491508.

Massey D (2005) For Space. London: Sage.

Mayor of London (2016) OPDC Strategic Review Findings - 31.10.16. Available at: https://www.london.gov.uk/sites/default/files/opdc review findings final 31.10.16 0.pdf (accessed 10 March 2020).

Mayor of London (2018) London Housing Strategy. London: Greater London Authority. Available at: https://www.london.gov.uk/sites/default/files/2018 lhs london housing strat egy.pdf (accessed 24 July 2018). 
Ministry of Housing, Communities and Local Government (2018) The Incidence, Value and Delivery of Planning Obligations and Community Infrastructure Levy in England in 2016-17. Available at:

https://www.gov.uk/government/publications/section-106-planningobligations-and-the-community-infrastructure-levy-in-england-2016-to-2017report-of-study (accessed 15 November 2021).

Mosselson A (2016) 'Joburg has its own momentum': Towards a vernacular theorisation of urban change. Urban Studies 54(5): 1280-1296.

Moulaert F, Rodriguez A and Swyngedouw E (2003) The Globalized City: Economic Restructuring and Social Polarization in European Cities. Oxford: Oxford University Press.

Murray M (2017) The Urbanism of Exception: The Dynamics of Global City Building in the Twenty-First Century. Cambridge: Cambridge University Press.

Old Oak Park Royal Development Corporation (OPDC) (2018) Old Oak North Development Framework Principles, Local Plan Supporting Study 32, Consultation June 2018. OPDC: $\quad$ City Hall, London. Available at: https://www.london.gov.uk/sites/default/files/32._old_oak_north_development framework_principles 1.pdf (accessed on 12 September 2018). 
Parker A and Appelbaum A (2020) On the defensive: the residential strategies shaping densification in Johannesburg's northern suburbs. In: Rubin M, Todes A, Harrison P and Appelbaum A (eds) Densifying the City: Global Cases and Johannesburg. London: Edward Elgar, pp. 202-212.

Parnell S and Pieterse E (2016) Translational global praxis: rethinking methods and modes of African urban research. International Journal of Urban and Regional Research 40(1): 236-246.

Parnell S and Robinson J (2012) (Re)theorising cities from the global south: looking beyond neoliberalism. Urban Geography 33(4): 593-617.

Patel S, Baptist C and D'Cruz C (2012) Knowledge is power - informal communities assert their right to the city through SDI and community-led enumerations, Environment and Urbanization 24(1): 13-26.

Peck J (2013) Explaining (with) Neoliberalism. Territory, Politics, Governance 1(2): 132157.

Peck J (2017) Transatlantic city, part 1: Conjunctural urbanism. Urban Studies 54(1): 430. 
Peck J and Theodore N (2007) Variegated capitalism. Progress in Human Geography 31(6):731-772.

Peck J and Theodore N (2019) Still Neoliberalism? South Atlantic Quarterly 118(2): 245264.

Peck J, Theodore N and Brenner N (2009) Neoliberal Urbanism: Models, Moments, Mutations. SAIS Review XXIX(1): 49-66.

Pinson G (2009) Gouverner la ville par projet: Urbanisme et gouvernance des villes européenes. Paris: Presses de la fondation national des sciences politiques.

Raco M (2014) The Post-Politics of Sustainability Planning: Privatisation and the Demise of Democratic Government. In: Wilson J and Swyngedouw E (eds.) The Post-Political and its Discontents: Spaces of Depoliticisation, Spectres of Radical Politics. Edinburgh: Edinburgh University Press, pp.25-47.

Robinson J (2016) Thinking cities through elsewhere: comparative tactics for a more global urban studies. Progress in Human Geography 40(1): 3-29.

Robinson J (2021) New territories of urban politics. In: Million A, Haid C, Castillo Ulloa I and Baur N (eds) Spatial Transformations: Kaleidoscopic Perspectives on the Refiguration of Spaces. London: Routledge, pp.269-285. 
Robinson J and Attuyer K (2021) Extracting Value, London Style: Revisiting the Role of the State in Urban Development. International Journal of Urban and Regional Research 45(2): 303-331.

Robinson J, Harrison P, Shen J and Wu F (2021) Financing Urban Development, Three Business Models: Johannesburg, Shanghai and London. Progress in Planning, Vol. 154. DOI: 10.1016/j.progress.2020.100513.

Schmid C (2005) Theory. In: Diener, R, Herzog J, Meili M, de Meuron P and Schmid C Switzerland: An Urban Portrait. Basel: Birkhauser, pp.163-223.

Schmid C (2008) Henri Lefebvre's theory of the production of space: towards a threedimensional dialectic. In: Goonewardena K, Kipfer S, Milgrom R and Schmid C (eds) Space, Difference, Everyday Life: Reading Henri Lefebvre. London: Routledge, pp.27-45.

Schmid C (2015) Specificity and urbanization: A theoretical outlook. In: Basel ES, Diener R, Herzog J et al (eds) The Inevitable Specificity of Cities. Zurich: LarsMuller Publishers, pp. 287-307. 
Schmid C, Karaman O, Hanakata N, Kallenberger P, Kockelkorn A, Sawyer L, Streule M and Wong KP (2018) Towards New Vocabularies of Urbanization Processes: A comparative approach. Urban Studies 55(1): 19-52.

Scott A and Storper M (2015) The nature of cities: the scope and limits of urban theory. International Journal of Urban and Regional Research 39(1): 1-16.

Shatkin G (2017) Cities for profit: the real estate turn in Asia's urban politics. Ithaca, NY: Cornell.

Shen J, Luo X and Wu F (2020) Assembling mega-urban projects through state-guided governance innovation: the development of Lingang in Shanghai. Regional Studies 54(12): 1644-1654.

Swyngedouw E (2005) Governance Innovation and the Citizen: The Janus Face of Governance-beyond-the-State. Urban Studies 42(11): 1991-2006.

Todes A and Robinson J (2020) Re-directing developers: New models of rental housing development to re-shape the post-apartheid city? Environment and Planning A: Economy and Space 52(2): 297-317.

Travers T (2004) The Politics of London: Governing an Ungovernable City. Basingstoke: Palgrave Macmillan. 
Wang Z and Wu F (2019) In-situ marginalisation: social impact of Chinese mega-projects. Antipode 51(5): 1640-1663.

Wu F (2018) Planning centrality, market instruments: governing Chinese urban transformation under state entrepreneurialism. Urban Studies 55(7): 13831399.

Wu F (2019) Land financialisation and the financing of urban development in China. Land Use Policy. Epub ahead of print 14 December 2019. DOI: https://doi.org/10.1016/i.landusepol.2019.104412.

Wu F (2020) Adding new narratives to the urban imagination: An introduction to 'New directions of urban studies in China'. Urban Studies 57(3): 459-472. 